\section{GlobAllomeTree: international platform for tree allometric equations to support volume, biomass and carbon assessment}

\author{
Matieu Henry ${ }^{(1)}$, Antonio Bombelli ${ }^{(2)}$, Carlo Trotta ${ }^{(3)}$, Alfredo \\ Alessandrini ${ }^{(3)}$, Luca Birigazzi ${ }^{(1)}$, Gael Sola ${ }^{(1)}$, Ghislain Vieilledent ${ }^{(4)}$, \\ Philippe Santenoise ${ }^{(1)}$, Fleur Longuetaud ${ }^{(7)}$, Riccardo Valentini ${ }^{(2-3)}$, \\ Nicolas Picard ${ }^{(4)}$, Laurent Saint-André ${ }^{(5-6)}$
}

GlobAllomeTree is an international platform for tree allometric equations. It is the first worldwide web platform designed to facilitate the access of the tree allometric equation and to facilitate the assessment of the tree biometric characteristics for commercial volume, bio-energy or carbon cycling. The webplatform presents a database containing tree allometric equations, a software called Fantallomatrik, to facilitate the comparison and selection of the equations, and documentation to facilitate the development of new tree allometric models, improve the evaluation of tree and forest resources and improve knowledge on tree allometric equations. In the Fantallometrik software, equations can be selected by country, ecological zones, input parameters, tree species, statistic parameters and outputs. The continuously updated database currently contains over 5000 tree allometric equations classified according to 73 fields. The software Fantallometrik can be also used to compare equations, insert new data and estimate the selected output variables using field inventory. The GlobAllomeTree products are freely available at the URL: http://globallometree.org for a range of users including foresters, project developers, scientist, student and government staff.

Keywords: Forest Assessment, LULUCF, Trees Outside Forests, Database, Software, Communication

\section{Introduction}

The techniques for evaluation of forest resources, whether for estimating the volume, biodiversity, bio-energy or carbon are constantly evolving (Kleinn 2002, Tomppo et al. 2010). The estimation of forest land area has continuously been improved and particularly with advances in terms of remote sensing (FAO/JRC 2011, GOFC-GOLD 2010). Regarding the estimation of forest variables

such as volume, biomass and carbon stocks, the continually increasing number of forest models and tree allometries has contributed to improve the estimation of forest biomass per tree, sprout or stands (Henry et al. 2011b). As part of the introduction of systems for payments for ecosystem services, and particularly to enhance climate change mitigation activities, it is crucial to improve the accuracy of the estimates of emissions by

$\square$ (1) Food and Agriculture Organisation of the United Nations, Forest Department, v.le delle Terme di Caracalla, I-00153 Rome (Italy); (2) CMCC, Euro-Mediterranean Center on Climate Change, v. Augusto Imperatore 16, I-73100 Lecce (Italy); (3) DIBAF, Università della Tuscia, v. Camillo de Lellis, I-01100 Viterbo (Italy); (4) CIRAD, F-34398 Montpellier Cedex 5 (France); (5) CIRAD, UMR Eco et Sols, Ecologie Fonctionnelle et Biogéochimie des Sols et Agro-écosystèmes, F-34060 Montpellier (France); (6) INRA, UR BEF, Biogéochimie des Ecosystèmes Forestiers, F-54280 Champenoux (France); (7) INRA, UMR LERFoB, Laboratoire d'Etude des Ressources Forêt-Bois, F-54280, Champenoux (France)

@) Matieu Henry (matieu.henry@fao.org)

Received: Nov 16, 2012 - Accepted: Jun 14, 2013

Citation: Henry M, Bombelli A, Trotta C, Alessandrini A, Birigazzi L, Sola G, Vieilledent G, Santenoise P, Longuetaud F, Valentini R, Picard N, Saint-André L, 2013. GlobAllomeTree: international platform for tree allometric equations to support volume, biomass and carbon assessment. iForest 6: 326-330 [online 2013-07-18] URL: http://www.sisef.it/iforest/ contents/?id=ifor0901-006

Communicated by: Marco Borghetti sources and removals by sinks (Richards \& Jenkins 2007, Wunder 2005). Advances in scientific forestry research should contribute substantially to the establishment of a future climate regime since land use change emissions $1.1 \mathrm{Pg} \mathrm{C} \mathrm{yr}^{-1}$ - mainly from tropical deforestation - accounted for $12.2 \%$ of global anthropogenic greenhouse gases (GHG) emissions between 2000 and 2009 (Friedlingstein et al. 2010). However, large uncertainties $\left( \pm 0.7 \mathrm{Pg} \mathrm{C} \mathrm{yr}^{-1}\right)$ still exist, the most part stemming from the lack of consistent and wide application of models for estimating biomass (Brown et al. 1995, Melson et al. 2011, Ramankutty et al. 2007).

The most common method to assess forest biomass is based on tree allometric equations combined with forest inventories. Tree allometric equation relates wood volume or that of several tree components to stem diameter at breast height and/or to tree height and/or other dendrometric variables. Different methods exist for developing tree allometric equations depending on the objective (commercial volume, bio-energy, biomass or carbon), forest type (mono-specific plantation or pluri-specific forest), tree size, accessibility of the tree, forestry law, technical, financial and human capacities (Picard et al. 2012). As a consequence, the quality of the biomass estimates varies among allometric equations and depends on how the allometry has been constructed.

Since the development of stem volume and biomass equations is a laborious and timeconsuming process - especially the destructive harvesting of large trees - existing equations need to be compiled, compared and evaluated to facilitate identification of the gaps in the coverage of equations. The compiled equations can also be used to test and compare existing equations with new ones, as well as to validate process-based models. Although the number of available allometric equations has increased significantly in recent years, estimates of biomass have not necessarily improved. Biomass equations had been compiled for tropical, subtropical, temperate, and boreal trees or forests (Brown et al. 1989, de Jong et al. 2009, Henry et al. 2011b, Jenkins et al. 2003, Návar 2009, Schroeder et al. 1997, Ter-Mikaelian \& Korzukhin 1997). However, biomass equations for some ecosystems such as shrubland (Nàvar et al. 2002) or continents such as Africa (Chave et al. 2005) remain understudied. In addition, the access to documents reporting tree allometric equations is limited. Most of them are found in the scientific literature to which access is restricted. Currently, national and continental databases for allometric equations are few (Henry et al. 2011a, Návar 2009, Zianis et al. 2005) and should be continually updated. In addition, the existing databases are not harmonized 


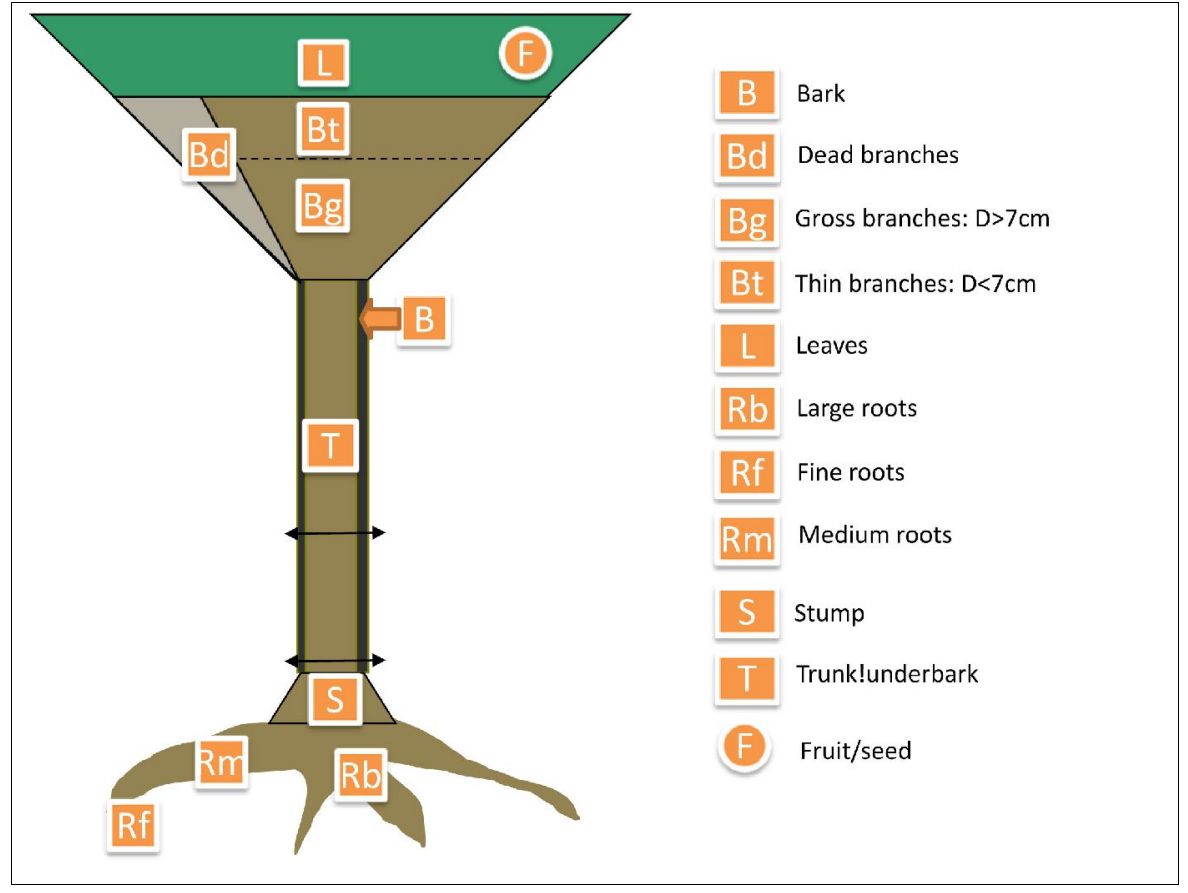

Fig. 1 - Different tree components as proposed by Henry et al. (2011b).

and data are often not comparable. Indeed, allometric equations correspond to different tree components (Fig. 1), different forest and management types, different intervals of validity and the estimated variables cannot be compared without preliminary alignment steps.

The choice of the most accurate allometric equation for biomass estimation is difficult in two cases (Henry et al. 2011a). First, more than one allometric equation may be available for a tree species and for a given ecological zone. Second, there may be no allometric equation for a given species or ecological zone or the available equations could not be reliable. It is crucial to have access to al- lometric equation databases to ascertain these potential issues. In both cases, several authors offer solutions taking into account the impact of the selected equation on carbon stocks and potential emission reduction calculations (Henry 2010, Melson et al. 2011).

Software and computer programs have largely contributed to improving forest estimates and facilitating the procedures of calculation (Masera et al. 2003, Nagel \& Schmidt 2003, Porté \& Bartelink 2002, Vanclay 1994). Widely used in developed countries, these softwares are usually specific to a country or an ecological zone. Currently, no software accounts for the great diversity of

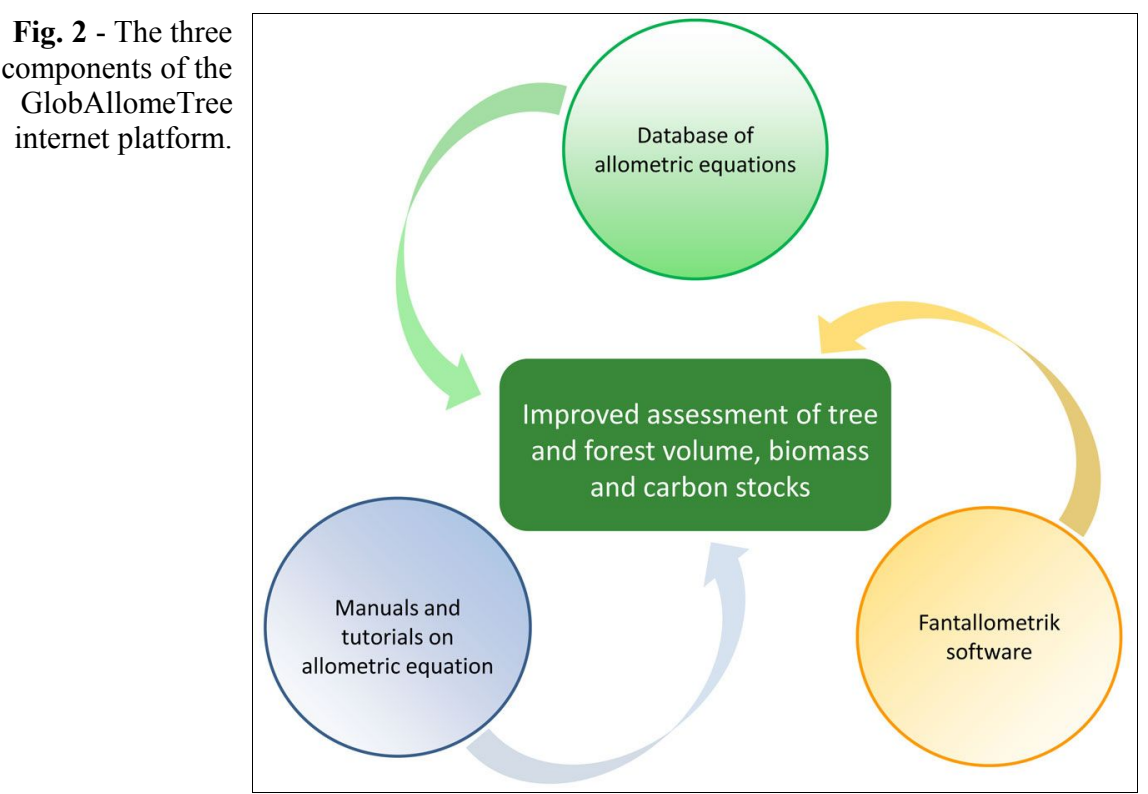

allometric equations, national circumstances and specific ecological zone classification.

The objective of this paper is to present the online platform "GlobAllomeTree" and our efforts to facilitate the development of a global tree allometric equations database and a software for volume, biomass and carbon assessment, using all existing source of allometric equations, but also to facilitate access to all the information related to tree allometric equation development.

\section{An internet platform to facilitate access to tree allometric equations}

The GlobAllomeTree online platform provides: (1) a consistent and harmonized database of tree allometric equations for volume, biomass and carbon assessment of trees at the global scale; (2) a software to estimate the variables of interest such as volume, biomass and carbon stocks taking into account the existing tree allometric equations; (3) easy access to scientific research information on allometric equation and assessment of volume, biomass and carbon stocks; and (4) access to tutorials and manuals supporting the use and the development of tree allometric equations (Fig. 2).

The platform is a unique and allows for the first time access to data that are generally difficult to access, either because they are in scientific journals, either because they are found in electronic documents or remote libraries. The tools provided are complementary and allow users to implement various steps from the field measurement to the prediction of volume, biomass or carbon stock. Data are available for different types of vegetation, from mangrove to plantations, from individual trees to stands. The tools target a large number of users, both for the assessment of forest resources and trees outside forests. Among the main users are people working on forest resource assessment (bioenergy trade volume, carbon stocks), scientists working on the dynamics of forest biometrics, forest technicians, students, and project developers involved in management of natural resources, especially forests.

\section{Tree allometric database to facilitate comparison and selection of allometric equation}

The web platform GlobAllomeTree provides free access to one global database for existing volume, biomass and carbon allometric equations for the different tree components identified in Fig. 1. The equations were georeferenced when possible from the original information. In some cases, it was not possible to access the original documents and the equations were not georeferenced. In the first version of the database, the number of equations is 706 for Europe (100\% georeferenced equations), 2843 for North America (74\% georeferenced equations), and 1058 


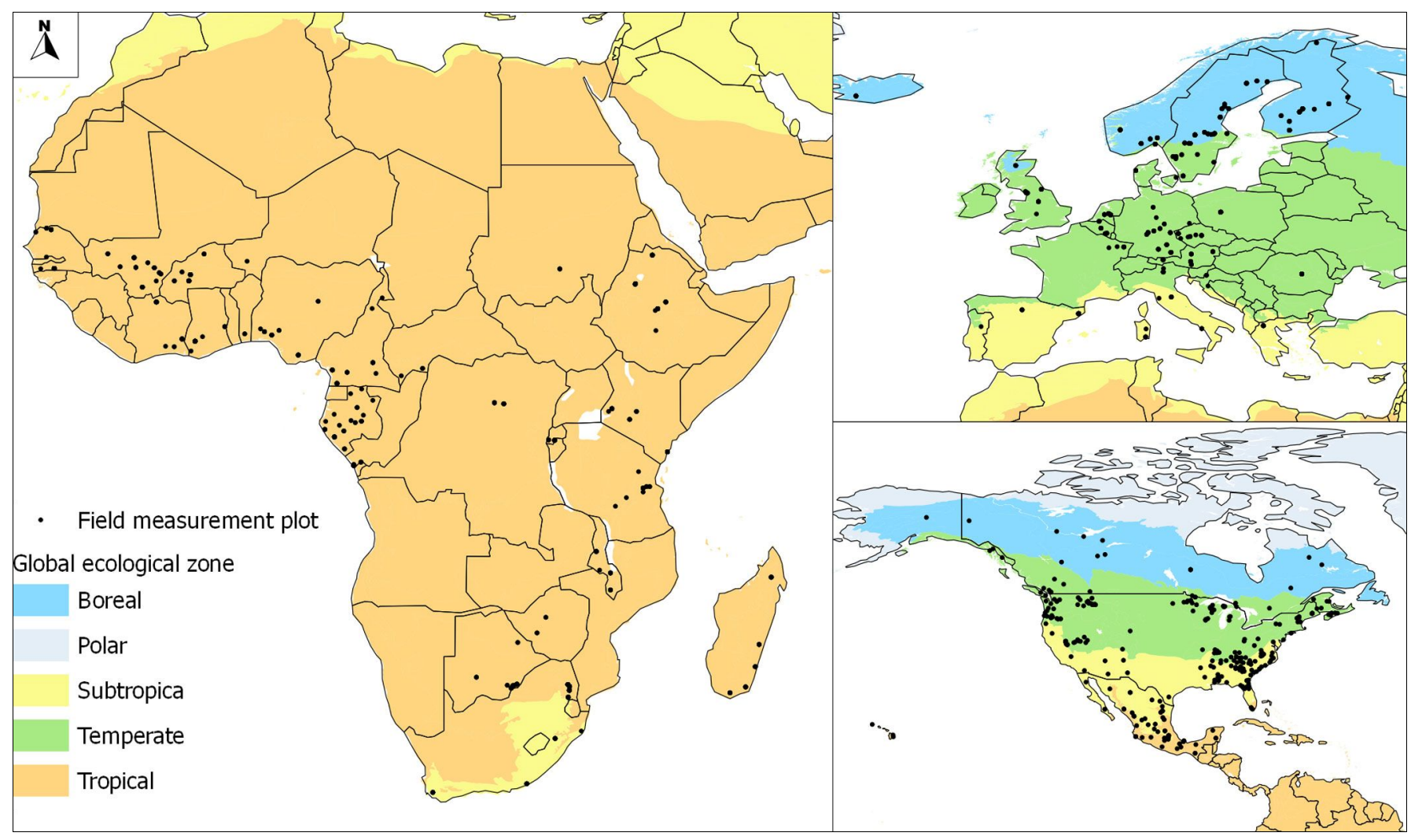

Fig. 3 - Geographic distribution of the georeferenced tree allometric equations in Africa, Europe and North America.

for Africa $(66 \%$ georeferenced equations Fig. 3).

Users can freely filter the database according to their needs (volume, biomass, carbon, edible foliage biomass, location, coun-

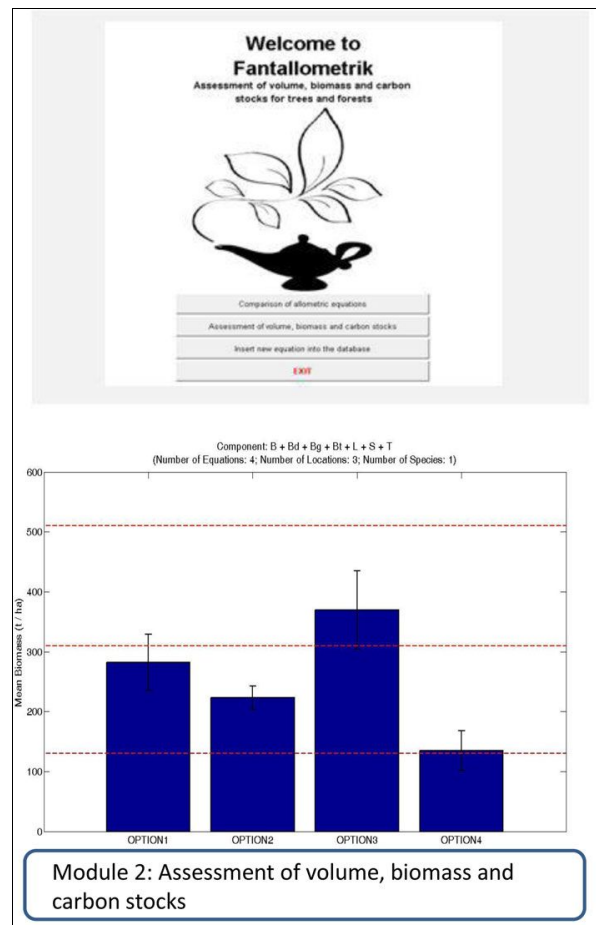

try, ecological zone etc). The software has been developed to cover many possible uses. The data were classified according to 5 ecological zone classifications (Holdridge, WWF, Bailey, FAO and Udvardy ecological

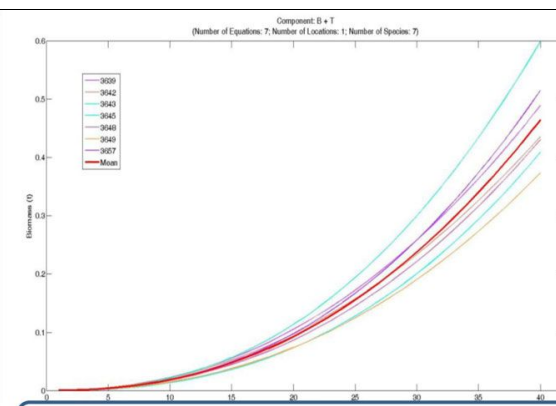

Module 1: Comparison of existing allometric equations

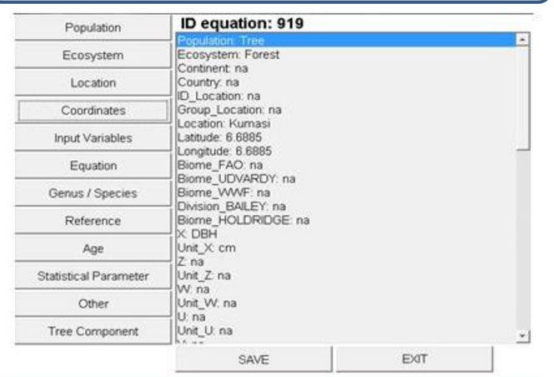

Module 3: Insertion of new allometric equations classifications are available at: http://www.carboafrica.net/data_en.asp) and eleven tree components (Fig. 1 ), by population types (stand, individual tree, sprout), and by forest type (plantation, natural forest etc).

An utmost care has been paid to avoid any transcription error from the primary literature to the figures reported in the database. However, may errors be detected, users are encouraged to send queries for updates and the database will be changed accordingly. Users are also encouraged to submit new allometric equations and databases to enrich the platform and contribute to the efforts.

\section{A software to use the allometric equation database and assess volume, biomass and carbon stocks}

A software was developed to facilitate the assessment of the volume, biomass and carbon stocks in native and secondary forests, plantations, tree outside forests, bamboos, lianas and mangroves (Trotta et al. 2013). The software was developed using the deploy tool made available for non-commercial use by Mathworks ${ }^{\odot}$ (http://www.mathworks.it/help/toolbox/compiler/deploytool.html). Users can upload the existing allometric equation database made available on GlobAllomeTree or develop their own. The software contains three main modules (Fig. 4): (1) comparison of existing tree allometric

Fig. 4 - The three modules of Fantallometrik software. 
equations; (2) assessment of volume, biomass and carbon stocks and automatically calculate from field measurement the volume and the biomass; (3) insertion of new allometric equations. The software is developed to give the possibility to insert new data. The user should careful read the detailed on-line guidance before starting to install and make calculations (Trotta \& Henry 2012).

The first module allows the user to filter equations according to his/her needs. The second module calculates the volume, biomass and carbon stocks using the selected equations. The user can import data from a field forest inventory plots and obtain the descriptive statistics for the allometric equations considered. The third module allows the user to automatically enter new equations that were not present in previous database. Users can submit entire databases or individual allometric equations.

\section{Conclusion}

In view of the importance of carbon stock assessment in forest ecosystems, the availability of allometric equations has long been a limitation. For the first time, the GlobAllomeTree portal enables users to access all of this information at once, so as to improve quality in the assessment of forest volume, biomass and carbon stocks. This platform represents a significant advance in forestry and climate related research and application, and we hope it will help improve estimates of biomass and emissions, for mitigation options, bioenergy to name but a few. The relevance of this issue is global, but there is an urgent need especially for tropical areas, where information is often scarce. The tools proposed by GlobAllomeTree internet platform allow the broad range of users involved in the assessment of the forestry resources to improve estimates of the most important forest variables. Moreover, this tool is dynamic and interactive, allowing a continuous improvement of the available equations and the inclusion of new ones. In the future, the addition of advanced biomass expansion factors and new statistical analyses should improve biomass estimates for the different tree components and carbon pools.

\section{Acknowledgements}

The Food and Agriculture Organization of the United Nations (FAO), the Centre de Coopération Internationale en Recherche Agronomique pour le Développement (CIRAD) and the Department for Innovation in Biological, Agro-Food and Forest System at Tuscia University (UNITUS-DIBAF) jointly developed this internet platform taking profit of the experiences built from several projects. We thank the European Union for funding the research required to the development of the platform through CarboAfrica (037132) and ClimAfrica (244240) projects. We also thank the UN-REDD program, the Agence Nationale de la Recherche (via the Emerge project), GeoCarbon (283080) and Global Terrestrial Observation System for their support. We thank Dr. Jérôme Chave (CNRS) for his contribution.

\section{References}

Brown S, Gillespie AJR, Lugo AE (1989). Biomass estimation methods for tropical forests with applications to forest inventory data. Forest Science 35: 881-902. [online] URL: http://www. winrock.org/ecosystems/files/Brown_Gillespie_e t_al_1989.pdf

Brown I, Martinelli LA, Thomas W, Moreira MZ, Cid Ferreira C, Victoria RA (1995). Uncertainty in the biomass of Amazonian forests: An example from Rondônia, Brazil. Forest Ecology and Management 75 (1-3): 175-189. - doi: 10.1016/ 0378-1127(94)03512-U

Chave J, Andalo C, Brown S, Cairns MA, Chambers JQ, Eamus D, Fölster H, Fromard F, Higuchi N, Kira T, Lescure JP, Nelson BW, Ogawa H, Puig H, Riéra B, Yamakura T (2005). Tree allometry and improved estimation of carbon stocks and balance in tropical forests. Oecologia 145 (1): 87-99. - doi: 10.1007/s00442-005-0100-

de Jong B, Rojas-García F, Olguín-Álvarez M, Martínez-Zurimendi P (2009). Base de datos con ecuaciones alométricas de árboles y arbustos de bosques y selvas de México. El colegio de la frontera sur unidad, Villahermosa, Tabasco, Mexico. [in Spanish]

FAO/JRC (2011). Global forest land-use change from 1990 to 2005. Initial results from a global remote sensing survey. Summary report, pp. 8. [online] URL: http://foris.fao.org/static/data/fra 2010/RSS_Summary_Report_lowres.pdf

Friedlingstein P, Houghton RA, Marland G, Hackler J, Boden TA, Conway TJ, Canadell JG, Raupach MR, Ciais P, Le Quéré C (2010). Update on $\mathrm{CO}_{2}$ emissions. Nature Geoscience 3 (12): 811-812. - doi: 10.1038/ngeo1022

GOFC-GOLD (2010). A sourcebook of methods and procedures for monitoring and reporting anthropogenic greenhouse gas emissions and removals caused by deforestation, gains and losses of carbon stocks in forests remaining forests, and forestation. GOFC-GOLD Project Office, Natural Resources Canada, Alberta, Canada, pp. 196. [online] URL: http://www.gofc-gold.uni-jena.de/ redd/sourcebook/Sourcebook_Version_Nov_200 9 cop15-1.pdf

Henry M (2010). Carbon stocks and dynamics in sub-Saharan Africa. Institute of Technology for Life, Food and Environmental Sciences (AgroParisTech), Paris, France and University of Tuscia, Viterbo, Italy, pp. 433.

Henry M, Maniatis D, Gitz V, Huberman D, Valentini R (2011a). Implementation of REDD+ in sub-Saharan Africa: state of knowledge, challenges and opportunities. Environment and Development Economics 16 (4): 381-404. - doi: 10.1017/S1355770X11000155

Henry M, Picard N, Manlay R, Valentini R,
Bernoux M, Saint-André L (2011b). Estimating tree biomass of sub-Saharan African forests: a review of available allometric equations. Silva Fennica Monographs 45:1-94. [online] URL: http://www.metla.fi/silvafennica/full/sf45/sf4534 77.pdf

Jenkins JC, Chojnacky DC, Heath LS, Birdsey RA (2003). Comprehensive database of diameter-based biomass regressions for North American tree species. GTR-NE-31, Northeastern Research Station, USDA Forest Service, Newtown Square, PA, USA, pp. 45.

Kleinn C (2002). New technologies and methodologies for National forest inventories. Unasylva 210. [online] URL: ftp://ftp.fao.org/docrep/fao/ 005/y4001e/y4001e01.pdf

Masera OR, Garza-Caligaris J, Kanninen M, Karjalainen T, Liski J, Nabuurs G, Pussinen A, de Jong B, Mohren G (2003). Modeling carbon sequestration in afforestation, agroforestry and forest management projects: the CO2FIX V.2 approach. Ecological Modelling 164 (2-3): 177199. - doi: 10.1016/S0304-3800(02)00419-2

Melson SL, Harmon ME, Fried JS, Domingo JB (2011). Estimates of live-tree carbon stores in the Pacific Northwest are sensitive to model selection. Carbon Balance and Management 6 (1): 2. doi: 10.1186/1750-0680-6-2

Nagel J, Schmidt M (2003). The single tree model BWINPro, a keycomponent for silvicultural decision support. In: Proceedings of the Conference "Decision support for multiple purpose forestry. A transdisciplinary conference on the development and application of decision support tools for forest management" (Vacik H ed). University of Natural Resources and Applied Life Sciences, Vienna (Austria) 23-25 April 2003, pp. 19. [CD-Rom]

Nàvar J, Méndez E, Dale V (2002). Estimating stand biomass in the Tamaulipan thornscrub of northeastern Mexico. Annals of Forestry Science 59 (8): 813-821. - doi: 10.1051/forest:2002079

Návar J (2009). Biomass component equations for Latin American species and groups of species. Annals of Forest Science 66 (2): 208. - doi: 10.1051/forest/2009001

Picard N, Saint-André L, Henry M (2012). Manuel de construction d'equations allométriques pour l'estimation du volume et la biomasse des arbres. Centre de Coopération Internationale en Recherche Agronomique pour le Développement, Food and Agriculture Organization of the United Nations, Rome, Italy, pp. 211. [in French]

Porté A, Bartelink HH (2002). Modelling mixed forest growth: a review of models for forest management. Ecological Modelling 150 (1-2): 141188. - doi: 10.1016/S0304-3800(01)00476-8

Ramankutty N, Gibbs HK, Achard F, DeFries R, Foley JA, Houghton RA (2007). Challenges to estimating carbon emissions from tropical deforestation. Global Change Biology 13 (1): 51-66. - doi: 10.1111/j.1365-2486.2006.01272.x

Richards M, Jenkins M (2007). Potential and challenges of payments for ecosystem services from tropical forests. Forestry Briefings 16: 8. 
[online] URL: http://www.odi.org.uk/sites/odi. org.uk/files/odi-assets/publications-opinion-files/ 816.pdf

Schroeder P, Brown S, Mo J, Birdsley R, Cieszewski C (1997). Biomass estimation for temperate broadleafforests of the United States using inventory data. Forest Science 43 (3): 424-434.

Ter-Mikaelian MT, Korzukhin MD (1997). Biomass equations for sixty-five North American tree species. Forest Ecology and Management 97: 1-24. - doi: 10.1016/S0378-1127(97)00019. 4

Tomppo E, Gschwantner T, Lawrence M (2010). National Forest Inventories: pathways for common reporting. Lavoisier, Paris, France, pp. 672.
Trotta C, Henry M (2012). Tutorial. Fantallometrik Software (version 1), pp. 34. [online] URL: http://www.globallometree.org/media/cms_page media/6/Tutorial fantallometrik.pdf

Trotta C, Henry M, Birigazzi L, Picard N, Sola G, Valentini R, Baldasso M, Saint-André L (2013). Fantallometrik software: assessing volume, biomass and carbon stocks for trees and forests. Journal of Systems and Software. [submitted] Vanclay JK (1994). Modelling forest growth and yield: applications to mixed tropical forests. ePublications@SCU, Southern Cross University Library, School of Environmental Science and Management Papers, CAB International, Wallingford, UK, pp. 330. [online] URL: http://epubs.scu.edu.au/cgi/viewcontent.cgi?article $=1538 \&$ context $=$ esm pubs

Wunder S (2005). Payments for ecosystem services: some nuts and bolts. Jakarta. Occasional Paper No. 42, CIFOR, Jakarta, Indonesia, pp. 32. [online] URL: http://www.cifor.org/publications/ pdf_files/OccPapers/OP-42.pdf

Zianis D, Petteri Muukkonen, Mäkipää R, Mencuccini M (2005). Biomass and stem volume equations for tree species in Europe. Silva Fennica Monographs 4: 63. [online] URL: http://www.metla.fi/silvafennica/full/smf/smf004 .pdf 